WOMEN, STATE AND IDEOLOGY 
Also edited by Haleh Afshar

IRAN: A REVOLUTION IN TURMOIL

WOMEN, WORK AND IDEOLOGY 


\section{Women, State and Ideology}

Studies from Africa and Asia

Edited by

Haleh Afshar

Lecturer in Economics

University of Bradford

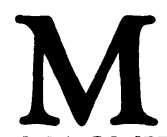

MACMILLAN

PRESS 
(C) Haleh Afshar 1987

All rights reserved. No reproduction, copy or transmission of this publication may be made without written permission.

No paragraph of this publication may be reproduced, copied or transmitted save with written permission or in accordance with the provisions of the Copyright Act 1956 (as amended).

Any person who does any unauthorised act in relation to this publication may be liable to criminal prosecution and civil claims for damages.

First published 1987

Published by

THE MACMILLAN PRESS LTD

Houndmills, Basingstoke, Hampshire RG21 2XS

and London

Companies and representatives

throughout the world

British Library Cataloguing in Publication Data

Women, state and ideology: studies from Africa and Asia.

1. Women-Developing countries-Social conditions

I. Afshar, Haleh

305.4'2'091724 HQ1870.9

ISBN 978-0-333-41390-6 ISBN 978-1-349-18650-1 (eBook)

DOI 10.1007/978-1-349-18650-1 


\section{Contents}

Acknowledgements

vii

Notes on the Editor and Contributors

viii

Glossary

$\mathrm{xi}$

Introduction

Haleh Afshar

PART I: WOMEN AND THE STATE

1 Women and the State in Nigeria: the Case of the Federal Military Government, 1984-5

Carolyne Dennis

2 Women in Zimbabwe: Stated Policy and State Action Susie M. Jacobs and Tracey Howard

3 The State and the Regulation of Marriage: Sefwi Wiawso (Ghana) 1900-40

Penelope A. Roberts

4 Women, Marriage and the State in Iran Haleh Afshar

\section{PART II: STATE AND POPULATION POLICIES}

5 Family and State in Malaysian Industrialisation: the Case of Rembau, Negeri Sembilan, Malaysia Maila Stivens

6 Gender and Population in the People's Republic of China

Delia Davin

7 Some State Responses to Male and Female Need in British India Jocelyn Kynch 
8 Contaminating States: Midwifery, Childbearing and the State in Rural North India

Patricia Margaret Jeffery, Roger Jeffery and Andrew Lyon

PART III: IDEOLOGIES, WOMEN AND THE LABOUR MARKET

9 Women and Handicraft Production in North India Ann Weston

10 Front and Rear: the Sexual Division of Labour in the Israeli Army

Nira Yuval-Davis

11 Controlling Women's Access to Political Power: a Case Study in Andhra Pradesh, India

Carol Wolkowitz

12 State, Culture and Gender: Continuity and Change in Women's Position in Rural Vietnam Christine Pelzer-White 


\section{Acknowledgements}

I would like to thank the Development Studies Association for funding and supporting the Women and Development Study Group. Thanks are similarly due to Steve Curry, who organised the Development Studies Conference at the University of Bradford, where many of the chapters of this book were presented. My thanks also to each of the contributors for participating in our numerous and heated discussion sessions and for making this book possible.

I would also like to thank Maurice Dodson, without whose constant help, support and encouragement this book would never have been completed. And Marlene Ellison for typing and circulating the reports of the group's meetings as well as the numerous drafts of some of the chapters, and for remaining patient, cheerful and unperturbed and for working beyond the call of duty to see this book through.

HaLeH AfShaR 


\section{Notes on the Editor and Contributors}

Haleh Afshar is a Lecturer in Economics at the University of Bradford, currently on secondment at the Centre for Health Economics, University of York. From 1972 to 1974 she worked both as a civil servant and a journalist in Iran. She is a founder member of the Development Studies Association's Women and Development Study group and edited the group's first book Women and Work in the Third World.

Delia Davin is a lecturer in Social and Economic History at the University of York. She taught in Beijing from 1963 to 1965, and worked as a translator there from 1975 to 1976. She has written extensively on women and the family in China, and her publications include: Woman Work: Women and the Party in Revolutionary China.

Carolyne Dennis taught and did research for seventeen years in Cameroon and Nigeria in West Africa on rural industrialisation, the labour market for women, the provision of health and plantation systems. She is now a Lecturer at the Project Planning Centre at the University of Bradford and is doing research on the labour market for women in West Yorkshire and a study of the institutional context within which Third World planners take decisions.

Tracey Howard is a pen-name.

Susie M. Jacobs is a Senior Lecturer in Sociology at St Mary's College, University of Surrey. She did her most recent fieldwork in Zimbabwe during 1983-4 when she was a Research Associate at the Ministry of Community Development and Women's Affairs.

Patricia Margaret Jeffery, after one year reading medicine, took a degree in Social Anthropology from Newnam College, University of Cambridge. She first visited South Asia while doing postgraduate research at Bristol University on Pakistani migrants (Migrants and Refugees, Cambridge University Press, 1976), and carried out further 
research among Muslims in Delhi in 1975-6 (Frogs in a Well: Indian Women in Purdah, 1979), returning to India in 1982 to carry out the research reported here. She is currently Lecturer in Sociology (parttime) University of Edinburgh.

Roger Jeffery read Economics at Churchill College, University of Cambridge, and did postgraduate research in the Sociology Department, University of Bristol with fieldwork in Lahore, Pakistan. He carried out further research in Delhi 1975-6 on the medical profession and medical policy-making (Health and State in India), and has acted as a consultant to maternal and child health programmes in India since 1979 . He returned to India in 1982 to carry out research reported here. Currently Lecturer (part-time) in Sociology, University of Edinburgh.

Jocelyn Kynch was a research assistant to Amartya Sen on the Leverhulme Trust funded project on forms and content of sex bias in living standards. She is a research officer at the Institute of Economics and Statistics, University of Oxford. She has visited India twice, conducting a nutritional survey of a village in Uttar Pradesh (supported by the ODA). Previous publications were in the areas of epidemiology, agricultural economics and criminology.

Andrew Lyon read Economics and Sociology at Edinburgh University and had an ESRC award for postgraduate research linked to the project reported here from 1981 to 1984 . He is currently writing a $\mathrm{PhD}$ thesis for the Sociology Department, University of Edinburgh.

Christine Pelzer White is a Research Fellow at the Institute of Development Studies, University of Sussex, with research interests in the socialist transformation of agriculture and women in socialist societies. During the academic year 1985-6 she is a visiting Associate Professor at the Graduate School of International Studies, University of Denver. She is co-editor of Revolutionary Socialist Development in the Third World (1983).

Penelope A. Roberts teaches at the University of Liverpool. She is an anthropologist and has carried out research in Ghana and Nigeria. She has co-edited a book on rural development in Africa and written several papers on women, rural development, and agrarian economies of Africa. 
Maila Stivens was born in Australia and studied Anthropology at Sydney University and the London School of Economics. She has carried out research in Sydney on kinship in a middle-class suburb and in Negeri Sembilan, Malaysia on gender and underdevelopment. A founding editor of Critique of Anthropology, she lives in London with her spouse and child and teaches at the University College, University of London.

Ann Weston is a development economist, currently working for the Commonwealth Secretariat, concentrating on international trade issues. She wrote this paper while employed as a research officer at the Overseas Development Institute.

Carol Wolkowitz is employed at the University of Bradford, where she is involved in a research project on women and home working, and has a one-year-old son. She has been active in the Conference of Social Economists.

Nira Yuval-Davis has been involved in anti-sexist and anti-racist struggles in both Israel and Britain, where she is a Senior Lecturer in Sociology at Thames Polytechnic, London, and where she is currently involved in a project on ethnic and gender divisions in southeast London. Her writings include topics such as the Israeli-Arab conflict, the interrelations of socialism and nationalism in radical Jewish movements and the theorisation of gender versus class ethnic and national divisions. 


\title{
Glossary
}

\author{
abusua dihyie royal matrilineage \\ adat matrilinear practices \\ adidi sika chop money \\ aliya wave of immigration \\ asetena bo marriage ceremony \\ a-sudh naturally impure, also called na-pak \\ awowa a pawn \\ ayefere adultery fee
}

Ayurvedic an indigenous system of sophisticated 'high culture' medicine derived from the Sambrit vedas (Hindu religious work) and associated with Hindu culture

babaso gonorrhoea

bhangan female member of the Hindu Bhangi caste whose traditional work is to sweep away the night soil, an occupation which makes her a member of the untouchable caste

chamar a Hindu intouchable caste, traditionally leather workers

chen charm the women's corp of isarael army

chikan embroidery

co giao Miss Teacher

dai traditional village midwife with no training

desi local, with undertones of inferiority; of superiority when compared with some non-local items

di amoen drink the gods

diyat blood money

eddeh a two- or three-month waiting period observed by Muslim women on divorce, before re-marriage

egya full marriage

esiase to put her behind (divorce payment)

ganda filthy, dirty with undertones of natural impurity, e.g. 'ganda-kam' means dirty work

goan village or settlement

goan ki dai the village traditional birth attendant

harijans 'Children of God', Gandhi's term for the 'untouchable'. According to the ideology of caste, their very touch is polluting.

hejab the Islamic veil

hoshiyar intelligent, knowledgeable, clever 
issar extreme generosity

kaam work, job

Kanouneh Vokala the Law Association

kari-to-ye a debt on the wife to be thrown away

k)k) knocking-fee

majbour neccessary

majbouri main of neccessity (literally in neccesity)

Majlis the Iranian Parliament

mpata pacification money

Mojtahed Shiia religious leader; entitled to interpret the Quranic dictum for his followers

Mojtahedin plural of Mojtahed

naal a tube or pipe, in the context of birth and new-born baby the umbilical cord

naal khatney-wali the woman who cuts the cord, the cord-cutter

na-pak naturally impure, the same as a-sudh

oman state

omanhene head of state

parda literally 'curtain', but used to describe the system of seclusion for women

parda-nashin a woman who keeps purdah; also 'respectable women who are debarred by national custom from appearing in public' (Indian Famine Code)

qanouneh Taazirat secular code relating to legal matters not specifically stated in the Quran

qassas the Iranian law of retribution

safohenes head of subordinate royal lineage

seh palat altering the pattern of a woman's birth order by prescribing treatment to ensure the sex of a foetus is male (or female).

sharm shame or embarrassment

sharm ki baat embarrassing matters

soma gya a marriage established by the payment of $k$ ) k)

Thanh Tam agony aunt

ti nza head rum, a form of marriage payment

ti sika head money

tutu prostitute

Unani or Greek (medicine) a system of sophisticated 'high culture' medicine brought to India by Mogul invaders from the Middle East and associated with Muslim culture

yishuv the pre-state Jewish settlement in Palestine

zabandar behaving in a speaking manner

zahal Israel defence army 